\title{
The Need of Speaking Course Teaching Materials Development in Indonesian Language Education Study Program (PBIN) of Peradaban University
}

\author{
${ }^{1}$ Cintya Nurika Irma, ${ }^{2}$ Sarwiji Suwandi, ${ }^{3}$ Ririn Setyorini \\ 11cintya_nurikairma@yahoo.co.id, ${ }^{2}$ sarwijiswan@yahoo.com, ${ }^{3}$ ririnsetyorini91@gmail.com \\ ${ }^{1}$ Universitas Peradaban University Purworejo, Indonesia, \\ ${ }^{2}$ Universitas Sebelas Maret Surakarta, Indonesia \\ ${ }^{3}$ Universitas Peradaban Bumiayu, Indonesia
}

\begin{abstract}
This study aims to describe and explain: (1) speaking course teaching materials used in Indonesian Language Education study program of Peradaban University, and (2) teaching materials needed by the lecturers and students in Indonesian Language Education study program of Peradaban University. The method used was descriptive qualitative. Data gathering method used document analysis, questionnaire, and interview. The data analysis technique used interactive analysis model. The result showed that (1) the available speaking course teaching materials doesn't include supporting information, exercises, instruction, and assessment and (2) the teaching materials needed by the lecturers and students should consider a) the easy to understand and unambiguous diction, b)the topic that should fit to the students' problem, c) the existence of exercises and task that are easy to understand,d) the existence of instruction and assessment for exercises and written tasks, e) the effectiveness of the teaching materials that should be ready to use in minimum condition of the university.
\end{abstract}

Key words: teaching materials, speaking, university

\section{Introduction}

Students are required to be able to realize four language skills, one of which is able to demonstrate the skill in speaking. This speaking ability is used to interact with campus communities who have a high intellectual level. Therefore, the students need to understand the nature of speaking, the reason for speaking, and the purpose of speaking as a reflection of critical, creative, descriptive, and argumentative thinking[1]. The problem often encountered when using spoken language is the speaker neglects the language action ofcourtesy of speaking. The language action includes the use of language verbally and nonverbally. The ability to choose the words of a speaker can be one of the determinants of the politeness of the language that is used to express meaning or purpose in a particular context so that it has the expected effect on speech partners

The use of language in speaking politely gets less attention. That is why we often find someone speaks in a good language and grammar, but the sense of the language often hurts the listeners. It is because the speakers do not know that there is politeness structure in the language. This phenomenon still gets less attention from the language experts. The structure of polite language and linguistic factors such as articulation, pitch, variation in loudness and softness of speech, speed of speech, and pauses are still problems that are closely faced by speakers when speaking. In addition, nonverbal politeness regarding movements such as bending the body, not glaring eyes, widely opening the legs, chin that is too thrust, and many more cannot be overcome maximally[2].

. The problem is overcome by the Indonesian Language Education in Teacher Training and Education faculty of Peradaban University by implementing Speaking 1 in semester 1 and 
Speaking 2 in semester 3 in order to equip the student in understanding and increasing speaking ability.. Based on the result of observation and interview with the lecturer of Speaking 1, it can be identified that there are eight problems causing the ineffectiveness of speaking course in Indonesian Language study program. First, there is a low interest of the students on speaking course. Second, the students have difficulty in choosing the diction. Third, the students are not accustomed to implement nonverbal politeness in communication. Fourth, the students are only led to the individual appearances.

. Fifth, students do not understand how to deal with nervousness, sound processing, and the success of speaking. Sixth, there is no availability of speaking textbooks as additional material to increase student knowledge. Seventh, students only have lack chance to speak publicly and the practice of speaking is only done in the classroom. Eighth, students are less confident to face public speaking. The unavailability of speaking textbooks should be a concern to take an action like realizing the development of speaking teaching materials that are tailored to the needs of students, study program, university and the community. Furthermore, Indonesian Language Education is a new study program in Peradaban University in 2015 and the course is still firstly taught for students in academic year 2016, so that the course does not have any main textbook or teaching materials.

The unavailability of main textbook used in the teaching learning process will make student difficult in learning the speaking course deeply. In choosing the teaching materials, it should consider some aspects such as (1) title, (2) learning materials, (3) standard of competences, (4) basic competences, (5) indicators, (6) learning instruction, (7) learning goal, (8) supporting detail, (9) exercises, (10) work instruction, and (11) assessment[3]. Another thing should be considered is that the textbook will be used by the students as a medium to develop their knowledge and ability in speaking with various skill such as the kind of speaking, situation, and topic that is match with the time and the need of university, study program, students, and communities.

In line with the research result of Faizah[4] entitled "the development of teaching materials of speaking course based on Cooperative Learning Think-Pair-Share (TPS) in Muhammadiyah University of Purworejo, it can be concluded that (1) according to the lecturers and students, the need of teaching materials should consider the language context, recent themein line with KTSP (Educational Unit Level Curriculum), the exercises and tasks that can stimulate to actively speak, the content of the materials that should be interesting and be ready to use in minimum condition of the university, (2) prototype should be developed into TPS-based teaching materials of speaking course by compiling the syllabus and lesson plan, making materials and authentic task, doing assessment process based on classroom assessment, (3) the results of the effectiveness test with the results of the non independent $\mathrm{t}$ test showed that teaching material was effective, (4) the result of the feasibility test of the teaching materials development was good with the component of content evaluation of $78 \%$, linguistic of $76 \%$, material presentation of $78 \%$, and graphics of $79 \%$.

Based on the learning result of speaking 1 course, it can be concluded that the Indonesian Language Education students' speaking ability in the academic year of 2016/2017 has not met the completeness criteria yet, which is 70.50 . There were 16 students got grade of $70-85$ out of 23 students. The teaching materials also should include exercises and tasks that in line with the situation of speaking, formal or informal, that want to be taught and nurtured within the students. Teaching materials development is important as the implementation of the need of choosing the proper learning materials. The lecturer knows more about this need, so that they can adjust it. 
According to the above statement, a teaching material is arranged in order to (1) provide teaching materials that are in accordance with the curriculum requirements by considering the needs of students, that is the teaching materials that are in accordance with the characteristics and settings or social environment of students, (2) help the students in obtaining alternative teaching materials in addition to text books that are sometimes difficult to obtain, (3) make it easier for teachers to carry out teaching learning process[3]. Then, this study is conducted in order to describe and explain (1) speaking teaching materials used in the Indonesian Language Education study program so far and (2) teaching materials needed by the lecturers and students in the Indonesian Language Education study program Peradaban University.

\section{Literature review}

\section{A. the Nature of Speaking}

Speaking is a language skill that develops in a child's life, which is only preceded by listening skills and in those days the ability to speak is learned[5]. Speaking is an oral linguistic skill supported by listening and reading skill done continuously for specific purpose that is adjusted from variety of speech. According to Kusuma[6], the success of generating influence and ideas through speech is closely related to the ability to process words, body language, equipment, and the environment of talk as well as preparation for speaking in public. Furthermore, the speaker can determine the four methods that can be selected according to the characteristics of the event and the self ability, those are: (1) direct speaking, (2) speaking without any preparation, (3) speaking using concept, (4) speaking from the memory.

The speakers should be able to evaluate the effect of their speech to the listeners and should know the principles underlying the speaking situation, both generally and individually. It can be done by analyzing what, how, when, where, why, and who we speak to, and linguistic and non linguistic factors. Linguistic factors should be consider by the speaker as the speaking effectiveness support consist of (1) speech accuracy, (2) placement of pressure, tone, principle, and duration, (3) diction, (4) accuracy of the target of the conversation. In addition, non linguistic factors should be nurtured to support the linguistic factors, such as (1) reasonable, calm, and flexible attitude, (2) the eyes that must be directed to the listeners, (3) willingness to respect the opinions of others, (4) the right gestures and expression, (5) loudness o voice, (6) fluency, (7) reasoning, (8) topic mastery.

\section{B. Teaching Learning Process in University}

Speaking is one of linguistic skills instead of listening, reading, and writing. Thus, the four aspects should be given in integrated in linguistic learning in equal proportion. Continuous speaking learning should get attention. Though speaking is done at any time, it needs an understanding and improvement of speaking ability, especially for intellectual people. Faizah[4] added that the high demand for information development contributes to speaking activity. This activity is carried out in line with the increasing importance of communication in public that demand professionalism of speaker.

Speaking course in university should be led to make students be able to develop public speaking skill in a wide range of formal and informal situation, so that the students have direct experience that can be applied in the formal and informal situation. Therefore, students need experiences can be applied in real social life and work situation. The speaking material include (1) basic concept of speaking, (2) factors influencing the speaking effectiveness, (3) the analysis of speakers' error, (4) variety of public speaking, and(5) the nature and the practice of Master of Ceremony, moderator, debate, interview, speech, andtale. 
Nurgiyantoro[7] said that there are authentic speaking task and other competences of speaking exercises. First, in authentic speaking task, the students are not only ordered to speak orally but also to consider the content of the conversation. The accuracy of speaking can be seen from the accuracy of the language used and the clarity of the speaking in the certain clear topic. Second, there are eight forms of speaking tasks, those are: (1) image-based speaking,(2) audio stimuli-based speaking, (3) audio and visual-based speaking, (4) storytelling,(5) interview, (6) discussion and debate,(7) speech. The assignment should be done in an interesting and enjoyable way so that students do not feel pressured and can express their language competence normally and maximally.

\section{C. the Nature Teaching Materials}

Teaching materials are a set of materials of learning contents to achieve learning objectives. A teaching material contains material or subject matter in the form of ideas, facts, concepts, principles, rules or theories that cover the subject according to their discipline and other information in learning[8]. Teaching materials have some objectives: (1) guidelines for teachers in carrying out systematic, precise and detailed systematic of learning, (2) guidelines for students as a continuous learning activity, (3) teaching materials are set based on the characteristics and needs of students, and (4) evaluation in teaching learning process. The teaching materials can utilize the available one or create a new one by choosing and developing it from various aspects especially social and culture.

Moreover, according to Majib[9], teaching materials can, at least, be divided into four: (1) printed materials such as handouts, books, modules, student worksheets, brochures, photos/picture, (2) audio teaching materials such as cassettes, radio, vinyl record, and compact disk audio, (3) visual teaching materials such as video compact disks, and films, (4) interactive teaching materials such as interactive compact disk. There are some reasons why it is necessary to develop teaching material: (1) the availability of materials according to curriculum requirements, meaning that the learning material developed must be in accordance with the curriculum,(2) target characteristics, meaning that the teaching material developed can be adapted to the characteristics of students as targets. These characteristics include the social, cultural, geographical and developmental stages of students, and (3) the development of teaching materials must be able to answer or solve problems or difficulties in learning[3].

\section{Research Method}

This research took 23 participants of semester III students in Indonesian Language Education Study Program of Peradaban University. The university is located in Jalan Raya (avenue) Pagojengan KM. 3, Paguyangan, Brebes Regency, Central Java 52276 (postcode). The method used was descriptive qualitative. The data collection techniques were document analysis, interview, and questionnaire. The triangulation techniques used in this research were source triangulation and method triangulation. Then it used the interactive analysis model as data analysis technique.

\section{Result and Discussion}

A. Research Result

(1) Speaking Teaching Materials used so far in Indonesian Language Education Study Program of Peradaban University

In Indonesian Language Education Study Program of Peradaban University, there are two kinds of speaking subject, speaking 1 in semester I and speaking 2 in semester III. In speaking 1 , the material is focused on the scope of speech and the practice of speaking in presenting an 
event in formal and informal situation. In speaking 2, the material given to students is related to the repetition of understanding the scope of speech along with the addition of practice as an effort to provide experiences for students in the community and work environment. In the academic year of 2017/2018, it is the first batch for semester III students of Indonesian Language Education to get speaking 2 after they finish speaking 1 in semester I.

Based on the interview with the lecturer in speaking 1, there are two conclusions. First, the learning result of the speaking 1 has not met the criteria for completeness, which is 70.50.From 23 students, there are only 16 students who get the score $70-85$, while the rest get under 69 score. It is because the students (1) find difficulties in speaking with various situations, (2) have not yet an experience of speaking in a formal and informal situation, (3) have not any reference book yet, and (4) can not solve the problem of anxiety in speaking. The second, it has been done a literature review on the textbook used that is a book written by Henry Guntur Tarigan entitled Berbicara Sebagai Suatu Keterampilan Berbahasa (speaking as a linguistic skill) published by Angkasa 2008[5].

Aspects used as feedback on the main textbook used in lecture include (1) the feasibility of content, (2) linguistic use, (3) presentation, and (4) graphic. First, from the content feasibility, the definition and explanation of the nature of speaking are in accordance with the materials delivered in speaking class. The weakness of the content is that the writer did not give any clear and specific example of speaking practice and tasks in a formal and informal situation. It is very crucial in a textbook. Then, from the linguistic use, the writer applied a good Indonesian language. The language used is effective, logic, and does not cause any multiple perceptions. Thus, it is easy to understand.

The third, from material presentation, the writer has not yet involve the readers to take a part in evaluating the understanding and skill after reading the theory on the book.Therefore, it needs exercise and assignment part for each sub material. Picture or ilustration is also needed in some parts to create interest and imagination during the learning process. The last one, from the graphic, the use of writing form, font size, paper, space, and layout are good enough. However, if there is an addition of the practice of speaking example through pictures, tables, etc., it will be even better and add the completeness of this section.

In addition, some other books are used by the lecturer, but only from some parts of them that make the students difficult to follow the lesson. Those are (1) Trik Kilat Kuasai Seni Berbicara (tricks to master speaking art quickly) written by Been Rafanani published by AraskhaPubisher 2017, (2) Mahir Pidato \& Bicara di Depan Umum (proficient in speech and public speaking) by Ristiani Yani Puspita Published by Notebook 2015, and (3) PembelajaranBerbicara (speaking course) by Ministry of National Education, Directorate General of Quality Improvement of Teachers and Education Personnel, Center for Development and Empowerment of Language Educators and Education Personnel 2009. The books have contained the scope of speaking materials, but, for university students, they do not have exercises and tasks for each competence that will be taught to students as part of developing self-understanding and ability. In addition, the section also functions as an evaluation stage for lecturers in determining the follow-up of learning outcomes obtained.

From the result of the interview with four students, it can be concluded that the problem faced by the students inlearning speaking are (1) the students find difficulty in making speaking text since writing 1 course is also done in the same semester, (2) the students often neglect nonverbal politeness, (3) the students are not accustomed to use proper language so they often use daily informal language such as biarin, anu, tak?, etc., (4) the students have low interest in learning speaking, (5) the students feel unconfident, (6) there is no teaching materials or textbook, (7) they have minimum direct practice, (8) the assignments or tasks are 
given only individually, not in pair, (9) the speaking exercises are only in the form of hosting and giving speech, and (10) the students have difficulty in disguising dialect intonation.

(2) Teaching Materials needed by the Lecturers and Students in IndonesianLanguage Education STUDY program of Peradaban University

From the questionnaire, it is gained that the expected materials of speaking variety to be taught in speaking 2 are practice of being MC, speech, radio broadcaster, moderator, and storytelling. The selection is based on the need to support the students' skill to speaking in university, society, and work circumstance. Besides, the students also find difficulty and have poor skill in the practice of being MC, speech, radio broadcaster, moderator, and storytelling. Practice of being MC is chosen because the students of Indonesian Language Education are usually selected as the MC in university events due to the assumption that the students have good skill speaking. However, some students often refuse to be $\mathrm{MC}$ in university or their surrounding events because they do not have adequate skill to be MC.

Then, Speech is selected too because the students often refuse to give a speech in events due to their lack experience though they have got the material in the previous subject. Third, practice as a moderator is selected in order to give the students understanding and experience in conducting a discussion in the lecture activities or outside the lecture. Fourth, radio broadcaster is selected as the students' choice to develop themselves in broadcasting. Fifth, storytelling is selected to give the students skills in making props, making fairy tale, telling a tale for preschool children until senior high school students. Below is the table of basic competencies and indicators in Speaking 2 subject.

Table 1 Basic Competencies and Indicators in Speaking 2 Subject

\begin{tabular}{ccc}
\hline No Basic Competences & Indicators \\
\hline 1 Speech & a) Understanding the nature of speech. \\
& b) Determining speech topic. \\
& c) Making speech text. \\
& d) Students are able to understand and analysis the speech \\
& form. \\
& e) Students are able to understand and analysis the \\
& presentation model of the speech. \\
& f) Identifying the preparation before the speech. \\
& g) Practicing in making speech message. \\
\hline 2 MC & a) Students understand the nature of MC. \\
& b) Students are able to identify the quality of MC. \\
& c) Students practice pronunciation technique. \\
& d) Students practice to hold and know the position of \\
& e) Students understand and analysis the kind of events. \\
& a) Students understand the nature of radio broadcaster. \\
& b) Students identify the requirements to be radio \\
& c) Students understand and practice the speaking style of \\
& d) Studionts identify the tools of radio broadcasting. \\
& e) Students understand the type of radio broadcasting. \\
& f) Sudents are able to indentify the duties of radio \\
\hline
\end{tabular}




\begin{tabular}{lll}
\hline No & Basic Competences & Indicators \\
\hline 4 & Moderator & broadcaster. \\
& a) Students understand the nature of moderator. \\
& b) Students understand and indentify things should be \\
& considered by moderator. \\
& c) Sudents practice to be moderator. \\
& d) Students analysis the activities of moderator. \\
& e) Students understand and practice a group discussion. \\
\hline 5 & Story telling & a) Students understand the nature of tale. \\
& b) Students understand the objectives and benefits of \\
& c) Students understand and identity the kinds of \\
& d) Students understand the requirements to be storyteller. \\
& e) Students understand and practice the technique of \\
& f) Students understand and practice making stage layout. \\
& g) Students understand and practice making props. \\
\hline
\end{tabular}

There are two categories of teaching materials used in speaking 2 subject, compulsory books and enrichment books. The compulsory books used are (1) Pengantar Keterampilan Berbicara (Introduction to Speaking) written by Umi Faizah published by Media Perkasa 2016[4], (2) Mempengaruhi dengan Kekuatan Bicara (affecting with speaking power) by Hendra Kusuma pulished by Pinus Book Publisher 2008[6], and (3) Public Speaking Kunci Sukses Berbicara di depan Publik Teori dan Praktik (Public Speaking, a key of success of speaking in public theory and practice) by Fitriana Dewi Utami published by Pustaka Pelajar 2013. The enrichment books used are (1) Mendidik Anak Lewat Dongeng (Educating the Children through Story telling) by M. Al-Qudsi published by Bintang Pustaka Abadi 2010, (2) Cara Gampang Jadi Penyiar Radio (an easy way to be radio broadcaster) by Saiful Bakhtiar published by Indonesia Cerdas 2007, (3) Buku Pintar Menjadi MC, Pidato, Penyiar Radio dan Televisi (Smart Book to be an MC, give Speech, Radio broadcaster and Television Announcer) by Burhan Fanani published by Araskatahun 2013, and (4) Public Speaking by Helena Olii published by Indeks 2007.

The compulsory and enrichment textbook stated above have different characteristics and learning materials scope. For example, the compulsory book entitled Pengantar Keterampilan Berbicara (Introduction to Speaking) written by Umi Faizah published by Media Perkasa 2016 is a developed book of speaking course textbook adjusted with condition and subject of the research in Muhammadiyah University of Purworejo. The book has 11 scopes of teaching materials that makes it qualified to be a good textbook. Similarly, Indonesian Language Education Study Program tries to develop two new materials, speaking as radio broadcaster and storytelling.

Based on the interview with the students, the use of these books has helped in the advanced process of speaking learning. However, there are some materials that are not integrated yet that require to take from some other books. Therefore, it is necessary to have a textbook that covers all of the materials though other books are still needed as supporting book. The language used in the book should be easy to understand, the topic is adjusted to the problem related to the students, there are exercises and tasks for each material that is easy to understand, there is work instruction, and assessment both for exercises and written tasks. Of course, there should be supporting facilities and infrastructure to practice these materials.

\section{B. Discussion}

There are four principles that are carried out to identify the rational selection, use, and development of needed speaking subject textbooks: philosophy, psychology, sociology, and organizational principle. From philosophy principle, the four linguistic skills need to be continuously developed until higher education. It can be continuously implemented in some subjects specifically and deeply. One of them is by increasing speaking skill. From the psychology principle, the success of speaking is determined by the self-awareness of the necessity of increasing the speaking skill and efforts to realize it. It is because of self-satisfaction that speaking has been learned since the early age so there is no need to learn the scope of speaking skills in depth. The understanding of the need to speak politely and in a good manner is often neglected.

The way of speakinglearning in university is given in some subjects, one of them is speaking subject. Indonesian Language Education Study Program applies the subject of speaking with various skills such as MC, moderator, presenting,da'wah (preaching), debate, and role playing that can be beneficial for students to face work field. The third principle is sociology principle. Social and cultural background should be considered when speaking. For example, in Java, people should use courtesy custom related to the person we talk to. When 
someone talks to another, nonverbal politeness is shown by ngapurancang (standing with two hands under the navel), indirectly look at the partner, indirectly saying something, and many more.

The fourth is the organizational principle. In this principle, there are three classifications of organization: (1) curriculum containing separated courses, (2) curriculum containing similar linked subjects, and (3) curriculum consisting of some joining courses. First, the speaking subject is a course separated from other subjects. Second, speaking subject is linked with other subjects like speaking 1, speaking 2, public speaking, and rhetoric. Third, the speaking subject is merger from some other subjects like listening, writing, and reading. The success of the organizational principle is an identifier in the preparation, implementation, evaluation, and follow-up for the lecturer in the subject, between the subjects and relevant courses and should be supported by the study program and faculty members.

Based on the result of observation and interview, it can be concluded that speaking course 1 does not have any main textbook yet that makes the students feel difficult in learning speaking materials. The other problem is that only a few students have the reference book and the library has limited book about speaking. Based on the questionnaire, it is known that (a) there are 23 students who want to increase their speaking skill, (b) there are 6 students who have more than a book, (c) there are 18 students who state that they find difficulties in speaking course, (d) there are 23 students who like getting speaking materials and tasks, (e) there are 23 students who answer that the speaking course has been done give enough speaking exercises, and (f) there are 16 students who actively ask when they find difficulties in learning.

Wisudaraini[10], in their research entitiled "the Development of Teaching Materials of Speaking Course II based on Character Education in Indonesian Language and Linguistic Education, Undiksa (Ganesha Education University) Singaraja" concluded that: (1) the teaching materials orders are: cover page, French page, acknowledgement, table of content, subject review, instructions for presenting teaching materials, map of teaching materials concept, instruction of teaching materials use, lecture strategies, and the unit of teaching materials, (2) based on validity result by experts of teaching materials content, the validity level is very good with percentage of response by $96 \%$, (3) based on the field test result, it can be concluded that the students be more enthusiastic and help them in understanding the lecture by using the textbook. The relevance of this research with the above research is in the term of discussing and analyzing the teaching material order, expert validation, and field test.

The research result of Wisudaraini, et al become the guidelines in selecting teaching materials used in Speaking Course 2 based on the results of the evaluation on Speaking Course 1. Books used in advanced speaking learning are categorized into compulsory books and enrichment books. There are 5 categories of textbooks needed by lecturers and students in speaking learning. First, the language selection should be easy to understand and should not cause ambiguity. The use of language in textbooks should consider the user of the book so that it can be easily understood by the reader. The important terms can be put into glossarium. The second, learning topic should be adjusted to students' problem related. The materials taught should be adjusted to the need of students, study program, faculty, university, and communities.

The third, there are exercises and tasks in each material that are easy to understand. The teaching books used need to have exercises in each material competency and need assignment as an evaluation of material. The fourth, there is work instruction and assessment for exercises and written tasks. The tasks and exercises require clear and systematic instruction. Furthermore, the lecturer needs to explain the assessment system for each assignment and the follow up for students who have not yet completed the minimum standard. The fifth, the teaching materials should be ready to use in the minimum condition of the university. The limited infrastructure and facilities of each university need to be dealt with by the use of teaching materials that can be implemented without the use of facilities or can be developed with available facilities such as radio, microphone, etc.

Teaching materials that have been used in Speaking Course 2 vary and are combined in accordance with the material and expected competencies including printed teaching materials, audio teaching materials, and visual teaching material. Printed materials used are book and students worksheet. Audio teaching materials used are cassetteand radio. Visual teaching materials used is video. There is a problem found in the practice of broadcasting since the university does not have broadcasting devices so that it is planned to make cooperation with Bumiayu Broadcasting station as a continuous practice place for students. In addition, it is hoped that the printed materials can be developed to be the guidelines for lecturers that are adjusted to the characteristics and the need of lecturer of speaking course, students of Indonesian Language Education study program, the study program, the faculty, and the university, and the local communities.

The research done by Ampa[11] entitled “The Students' Needs in Developing Learning Materials for Speaking Skills in Indonesia" concluded that (1) the students' need related to speaking skills in term of system are vocabularies $(92 \%)$, pronunciation $(88 \%)$, structure $(90 \%)$, and in term of function are interaction $(43 \%)$, transaction (92\%), and performance (92\%), (2) the analysis result showed that the students need printed materials $(75 \%)$, video $(73 \% 0$, audio $(58 \%)$, and image $(18 \%),(3)$ there are seven interesting topics for students: education, science and technology, economic, health, environment, language learning, and religion. The 
education topic attracts the students' interest by $75 \%$, and (4) the learning style used by the students are audio, visual, and kinesthetic, though the most used is audio style.

In line with the research of Ampa, the result of observation and questionnaire on the speaking course 2 of semester 3 students in Indonesian Language Education Study Program covers speaking skill with the need of vocabularies $(90 \%)$, pronunciation $(87 \%)$, structure $(96 \%)$, interaction $(89 \%)$, transaction $(88 \%)$, and performance $(77 \%)$. Then, the students need printed materials $(90 \%)$, video $(90 \%)$, audio $(77 \%)$, and picture (70\%). The interesting topics for students are education, religion, social, cultural, environment, language learning, and science and technology. Beside that, in speaking learning, there are 10 assessment aspects: (1) the conformity of speaking content, (2) the accuracy of speaking logic order, (3) the accuracy of the meaning of the whole story, (4) the diction, (5) sentence accuracy, (6) speaking fluency, (7) performance, (8) expression, (9) the clarity and speed of pronunciation, (10) speaking style. The ten assessment aspects have a range score of 1 until 5 that is shown in the following table.

Table 2 Speaking Assessment Rubrics

\begin{tabular}{|c|c|c|c|c|c|c|}
\hline \multirow{2}{*}{ No } & \multirow{2}{*}{ Assessed aspect } & \multicolumn{5}{|c|}{ Score } \\
\hline & & 1 & 2 & 3 & 4 & 5 \\
\hline 1 & The conformity of speaking content. & & & & & \\
\hline 2 & The accuracy of speaking logic order. & & & & & \\
\hline 3 & $\begin{array}{l}\text { The accuracy of the meaning of the whole } \\
\text { story. }\end{array}$ & & & & & \\
\hline 4 & The diction. & & & & & \\
\hline 5 & Sentence accuracy. & & & & & \\
\hline 6 & Speaking fluency. & & & & & \\
\hline 7 & Performance. & & & & & \\
\hline 8 & Expression. & & & & & \\
\hline 9 & The clarity and speed of pronunciation. & & & & & \\
\hline 10 & Speaking style. & & & & & \\
\hline
\end{tabular}

\section{Conclusion}

The Lecturers need to understand the learning objectives of the subject taught through the syllabus, lesson plan, and competency standards that are expected to be achieved by students. The selection and use of teaching materials to support learning achievement needs to be carefully identified. It is hoped that the students understand not only the theories but also the analysis and the practice. There are two conclusions of this research. First, speaking teaching materials used so far have not yet included supporting information, exercises, work instructions, and assessments. The second, the teaching materials needed by the lecturer and students should consider (1) the choise of the word or the diction that must be easy to understand and does not make any ambiguity, (2) the learning topic should be related to students' problem, (3) there are exercises and assignment for each material that is easy to understand, (4) there is work instruction and assessment guideline for exercises and written tasks, and (5) the teaching materials should be ready to use in the minimum situation of the university.

The speaking course got by semester III students of Indonesian Language Education ofPeradaban University is the first batch of the students who finish speaking course II. Thus, this research is merely an analysis of the teaching materials needed by the lecturers and students, especially in Indonesian Language Education of Peradaban University. Based on evaluation result, it can be concluded that there is a need to make follow up action related to the development of teaching materials that are adjusted to the characteristics and the need of the lecturer, students, faculty, university, and communities.It is hoped that the next researches can identify the materials of the teaching materials that are possible to develop in speaking course such as broadcasting and storytelling that have been don in speaking course 2 for the first time. Hopefully, the materials give additional competencies for students. The last one, of course, it should be adapted to the availability of facilities or use other options so that it can be realized.

\section{References}

[1] A. Setyonegoro, "Hakikat, Alasan, dan Tujuan Berbicara (Dasar Pembangun Kemampuan Berbicara Mahasiswa)," J. Pena, vol. 3 (1), pp. 67-80, 2013.

[2] Pranowo, Berbahasa Secara Santun. Yogyakarta: Pustaka Pelajar.

[3] D. P. S. M. Atas, Panduan Pengembangan Bahan Ajar. Jakarta: Departemen Pendidikan Nasional, 2008.

[4] U. Faizah, "Peran Mata Kuliah Retorika dalam Pembinaan Budi Pekerti dan Moral Bangsa (Studi Kasus Mahasiswa Pendidikan Bahasa dan Sastra Indonesia),” J. Surya Bahtera, vol. 1 (1), pp. 1-12, 2012.

[5] H. G. Tarigan, Berbicara Sebagai Suatu Keterampilan Berbahasa. Jakarta: Angkasa, 2008. 
[6] H. Kusuma, Mempengaruhi Dengan Kekuatan Bicara. Jakarta: Pinus, 2008.

[7] B. Nurgiyantoro, Penilaian Pembelajaran Bahasa Berbasis Kompetensi. Yogyakarta: BPFE, 2012.

[8] Sungkono, Pengembangan Bahan Ajar. Yogyakarta: Universitas Negeri Yogyakarta, 2003.

[9] A. Majid, Kurikulum dan Pengembangan Bahan Ajar. Jakarta: Ombak, 2013.

[10] N. . M. R. Wisudariani, Pengembangan Bahan Ajar Mata Kuliah Berbicara II Berbasis Pendidikan Karakter di Jurusan Pendidikan Bahasa Dan Sastra Indonesia. Universitas Pendidikan Ganesha, 2013.

[11] A. T. Ampa, "The Students' Needs in Developing Learning Materials for Speaking Skills in Indonesia," J. Educ. Pract., vol. 4 (17), pp. 171-179, 2013. 